NOV 131964

\author{
University of California \\ Ernest O. Lawrence \\ Radiation Laboratory
}

UCRL-7850 Rev. 1

' HETER

ECONOMICS OF GROUND WATER RECHARGE

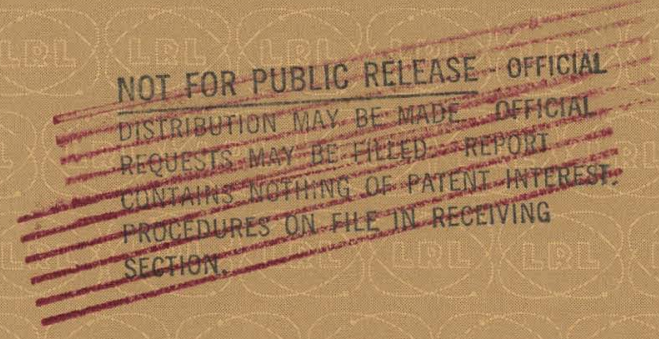

Livermore, California 


\section{DISCLAIMER}

This report was prepared as an account of work sponsored by an agency of the United States Government. Neither the United States Government nor any agency Thereof, nor any of their employees, makes any warranty, express or implied, or assumes any legal liability or responsibility for the accuracy, completeness, or usefulness of any information, apparatus, product, or process disclosed, or represents that its use would not infringe privately owned rights. Reference herein to any specific commercial product, process, or service by trade name, trademark, manufacturer, or otherwise does not necessarily constitute or imply its endorsement, recommendation, or favoring by the United States Government or any agency thereof. The views and opinions of authors expressed herein do not necessarily state or reflect those of the United States Government or any agency thereof. 


\section{DISCLAIMER}

Portions of this document may be illegible in electronic image products. Images are produced from the best available original document. 


\author{
UNIVERSITY OF CALIFORNIA \\ Lawrence Radiation Laboratory \\ Livermore, California \\ Contract No. W-7405-eng-48
}

\title{
ECONOMICS OF GROUND WATER RECHARGE
}

\author{
David K. Todd ।
}

September 28, 1964

This paper was submitted for publication in the open literature at least months prior to the issuance date of this Microcard. Since the U.S.A.E.C. has no evidence that it has been published, the paper is being distributed in Microcard

form as a preprint. 


\section{ECONOMICS OF GROUND WATER RECHARGE}

by

David K. Todd, ${ }^{1}$ M. ASCE

\section{SUMMARY}

Costs and benefits of artificially recharging ground water are reviewed to form a basis for economic evaluation of the technique. Alternative procedures, institutional and financial arrangements, and cost components are considered. Selected cost data, mostly from California projects, are summarized.

\footnotetext{
${ }^{1}$ Prof. of Civil Engineering, Univ. of California, Berkeley.
} 


\title{
ECONOMICS OF GROUND WATER RECHARGE
}

by

\author{
David K. Todd, M. ASCE
}

\section{SYNOPSIS}

Although artificial recharge of ground water is well known and widely practiced, little information on costs of the technique is available. This paper summarizes benefits and alternatives to artificial recharge, reviews cost components, and presents costs of selected projects. The value of water is reviewed followed by consideration of the direct and indirect benefits of recharging. Institutional and financial arrangements for artificial recharge projects are discussed. Particular attention is given to California's Water Replenishment District Act and the use of the replenishment assessment as a means for financing projects. A few data on costs of water wells and pumping ground water are presented because extraction of ground water is a part of the total recharge cost. Generalized cost estimates of various items involved in recharge projects are tabulated, followed by costs of actual projects in California and Illinois. Because of the variability of size, purpose, and method of operation, together with a wide range in land and water costs, no concise summary of recharge costs is possible. However, it is believed that the data assembled here will be useful to engineers planning and designing. such projects. 


\section{INTRODUCTION}

Today the purposes of artificial recharge of ground water in terms of conservation, storage, and purification are well known. Throughout the United States recharging is practiced wherever available ground water resources must be managed for maximum beneficial development. ${ }^{2}$ In the Southwestern United States, where arid climates and concentrations of population are combined, the technique has found greatest application as evidenced by its rapid expansion in the region. California alone recharges more water underground than all other states combined.

Although artificial recharge is widely practiced, little information has been assembled regarding its costs. Perhaps the reason lies in the fact that recharge projects vary greatly in size, purpose, and method of operation. Land and water costs are other significant variables. Yet, if engineers concerned with water resources management are to evaluate the economic feasibility of recharging, cost data must be collected and analyzed.

This paper attempts to summarize benefits and alternatives to artificial recharge, to review cost components of artificial recharge projects, and to summarize costs of selected artificial recharge projects.

\section{METHODS OF ARTIFICIAL RECHARGE}

Works for artificially recharging ground water are designed to increase infiltration rates, wetted area, and duration of infiltration over that occurring naturally. Most projects may be classified by method as follows: basins, modified stream beds, pits, ditches and furrows, flooding, and injection

wells. Richter and Chun ${ }^{4}$ showed that a.majority of projects in California were of the basin type, while the basin and modified stream.bed types accounted for more than 80 per cent of all water recharged. 
The various methods of artificial recharge have been extensively discussed in the literature ${ }^{5,6}$ so that further elaboration here is unnecessary.

\section{VALUE OF WATER}

In assessing the benefits of artificial recharge, consideration must be given to the importance of water to the total economy, to the value of water for various uses, as well as to the direct and intangible benefits which may accrue. Furthermore, because storage, underground distribution, and reuse of water are involved, the importance of the methodas a technological necessity for water resources development needs to be assessed.

Water is an extremely low-cost.item on a unit-cost basis, yet the large volumes consumed, together with the increasing costs of its.production, make impressive totals in terms of expenditures involved. Recently, in a worldwide review by Scientific American of technology and economic development, Revelle ${ }^{7}$ analyzed the role of water. The following excerpt is an excellent statement of the economic significance of water.

"Although it is usually not reckoned as such in economic statistics, water can be considered a new material. In the U.S. the production of raw materials has a minor role in the total economy, and water costs are small even when compared with those of other raw materials. The cost of all the water used by U.S. hous eholders, industry and agriculture is around $\$ 5$ billion a year: only 1 per cent of the gross national product. The less developed countries, where raw materials are a major component of the economy, cannot afford water prices that would be acceptable in the U.S.

"In the U.S. water costs. $\$ 10$ to $\$ 20$ an acre-foot, compared with wholesale prices of $\$ 22,000$ an acre-foot for petroleum, $\$ 100,000$ an acrefoot for milk and \$1 million an acre-foot (not counting taxes) for bourbon 
whiskey. The largest tanker ever built can hold less than $\$ 1000$ worth of water. Yet Americans use so much water - about 1700 gallons a day per capita - that capital costs for water development are comparable to other kinds of investment. Although the water diverted from streams and pumped from the ground is equivalent to only about 7 per cent of the rain and snow falling on the U.S. ; this is still an enormous quantity: 200 times more than the weight of any other material except air. The annual capital expenditure of water structures in the U.S. - dams, community and industrial water works, sewage-treatment plants, pipelines and drains, irrigation canals, river-control structures and hydroelectric works - is about $\$ 10$ billion.

"One of the most critical water problems in the U. S. is represented by the vast water-short region of the Southwest and the high Western plains. In some parts of the Southwest water stored underground is being mined at an alarmingly high rate, and new sources must soon be found to supply even the present population. The average annual supply of controllable water in the entire region is 76 million acre-feet. If agriculture continued to develop at the present rate, 98 to 131 jillion acre-feet would be required by the year 2000. Provided that the neighboring water-surplus regions could be persuaded to share their abundance, this deficit could be met by long-distance transportation of 22 to 55. million acre-feet per year. But the annual cost would be $\$ 2$ billion to $\$ 4$ billion, or $\$ 60$ to $\$ 100$ per acre-foot of water, including amortization of capital costs of $\$ 30$ billion to $\$ 70$ billion. The cost per acrefoot would be too high for most agriculture, although not too: high for municipal, $* \quad$ industrial and recreational needs.

"Nathaniel Wollman of the University of New Mexico and his colleagues have shown that the average value added to the economy of the Southwest through the use of water in irrigation is only $\$ 44$ to $\$ 5$ l an acre-foot,. whereas 
the value gained from recreational uses could be about $\$ 250$ an acre-foot and from industrial uses $\$ 3000$ to $\$ 4000$ an acre-foot. Because the quantities of water consumed by city-dwellers and their industries are much lesis than those in agriculture, the arid Western states would not require such a vast increase in future supply if they shifted from a predominantly agricultural to a predominantly industrial economic base."

It is clear that analysis of the benefits of artificial recharging is dependent upon what value can be assigned to a unit volume of water. The price of water varies widely, being controlled by its source, use, quality, and the economic criteria of supply and demand. In general, water for municipal and industrial purposes is priced at many times that for agricultural purposes. It is also apparent that prices of water are rising rapidly with the possible exception of agricultural water provided under Federal subsidy.

Renshaw ${ }^{8}$ analyzed the value of water in terms of use. His data are summarized in Table 1. Because water can be used for several purposes simultaneously, the aggregate value of water at any point is the sum of individual use values. In addition, water returned to a stream or reservoir may be used to generate values at other points of use.

Values in Table 1 are gros values as other appurtenant costs are included. For municipal and industrial water, for example, costs of purification and distribution are included. Renshaw points out that the net worth of water is difficult to determine because there is not an active market in water rights; therefore, the best estimate of relative water values may be either distributions of market prices paid for water at points of use or distributions of actual costs incurred in putting water to work. Comparison of gross values is often inaccurate as an arbitrary decision to include or exclude a given cost element could have a.significant effect. Although no attempt was 
made to assign monetary values to recreational and aesthetic attributes of water, it is apparent that these factors could become quite important for some water bodies.

TABLE 1. VALUE ÖF WATER IN THE UNITED STATES FOR VARIOUS PURPOSES, $1950^{8}$

\begin{tabular}{lcc}
\hline \multicolumn{1}{c}{ Purpose } & $\begin{array}{c}\text { Maximum Value, } \\
\text { dollars/acre-foot }\end{array}$ & $\begin{array}{c}\text { Mean Value, } \\
\text { dollars/acre-foot }\end{array}$ \\
\hline Domestic Water Supply & $\$ 235.66$ & $\$ 100.19$ \\
Industrial Water.Supply & 163.35 & 40.73 \\
Irrigation & 27.04 &. .67 \\
Power & 5.90 & 0.71 \\
Waste Disposal & 2.56 & 0.63 \\
Inland Navigation & 1.17 & 0.05 \\
Commercial Fisheries & 1.06 & 0.025 \\
\hline
\end{tabular}

The largest wholesaler of water in Southern California is The Metropolitan Water District of Southern California. Its water is transported from the Colorado River by aqueducts to markets in the coastal area from Los Angeles to San Diego. A majority of the District's income comes from an advalorem tax assessment, while a minor portion comes from water sales. The price schedule for Metropolitan Water District water is shown in Table 2 from its first delivery in 1940 to 1966 together with proposed water prices from 1966 to:1990. In 1958 separate rates for domestic and municipal use and for agricultural use and ground water replenishment were established. The differential recognized the limited ability to pay of agricultural users. $\therefore \quad$ It.was also designed to encourage agricultural use and artificial recharge of ground water reservoirs. This purpose has been served: in 1961-62 38.3 per cent of all imported Colorado River water was used. for ground water replenishment. 
TABLE 2.-PRICE OF COLORADO RIVER WATER SOLD BY THE METROPOLITAN WATER DISTRICT OF SOUTHERN CALIFORNIA, 1940-1990* (DOLLARS PER ACRE-FOOT)

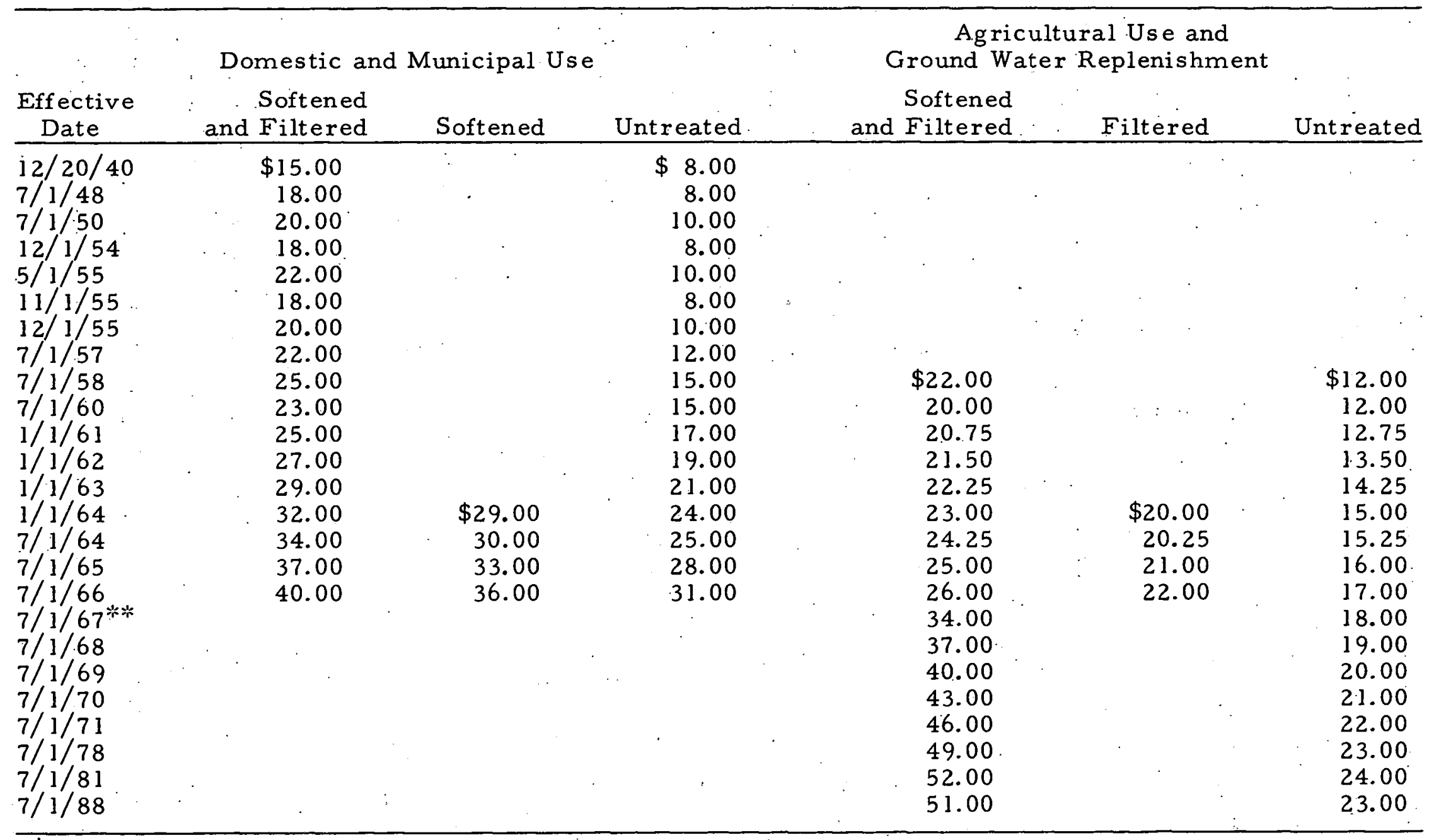

*Data from Miller ${ }^{9}$ (4) and data furnished by the District.

*** Rates on and after July 1, 1967 are proposed and have not yet been acted upon by the MWD Board. 


\section{- DIRECT. BENEFITS OF ARTIFICIAL RECHARGE}

Evaluation of benefits received from operation of a surface water system can be measured by estimates of the revenue which will accrue as a result of the project. However, artificial recharge projects are generally not so.susceptible of expression in explicit form. Organizations conducting recharging'may receive only partial benefit, identification of recharged water is often impossible, and quality differences may complicate monetary evaluations. The basic benefits of artificial recharge of ground water can be classified under two categories: (a) relief of overdraft, and (b) us e of ground water basins as cyclic storage and distribution systems.

By counteracting overdraft of a ground water basin, artificial recharge may provide the following: specific benefits:

(a) Lower operating costs for ground water supplies by lessening pumping lifts.

(b) Eliminate capital expenditures for purpose of deepening wells.

(c), Increase farm income as a result of augmented and dependable water supplies.

(d) Reduce incidence of premature abandonment of wells.

(e) Increased municipal expansion resulting from augmented subsurface water supplies.

(f) Prevent sea water intrusion into coastal aquifers.

(g) Prevent release of deep-seated connate brines into the aquifer.

(h) Prevent dewatering of all or part of the underground reservoir.

(i) Prevent land subsidence by sustaining ground water levels.

Use of underground reservoirs as storage and distribution systems is analogous to the operation of a surface reservoir and distribution system. The usable capacity of the ground water reservoir can be developed by 
planned extractions of ground water during periods of low precipitation, while subsequent replenishment can be made during periods of surplus surface supply. Such a conjunctive operation with surface and subsurface water supplies presupposes that there is sufficient ground water storage to meet requirements for regulation. of local and imported water supplies, and that the aquifers possess sufficient transmissibility to permit movement of recharged water to the area of extraction. The basic difference between the usual surface water development with its associated ground water development and conjunctive operation of surface and ground water reservoirs is that the separate firm y-ields of the former may be replaced by a more economic joint yield in the latter. ${ }^{3}$

The benefits of conjunctive operation of all water resources are several. These include:

(a) Saving in cost of developing equivalent usable storage capacity in a surface storage reservoir.

(b) Saving in cost of constructing an equivalent surface distribution system and with regard to peak requirements.

(c) Increased total water supply available for use.

(d) Small drainage system required in irrigated areas as wells aid in controlling the water table.

(e) Reduced canal lining as seepage from canals becomes a benefit as artificial recharge.

(f) Greater flood control as release of stored surface waters for artificial recharge reduces the flood control reservation.

(g) Smaller evapotranspiration losses for water stored underground than above ground. 
(h) Improvement of power load and pumping plant use factors in areas served by either surface or ground water, as surface water çan be released for irrigation during peak power demand.periods to effect a saving in power costs.

\section{INTANGIBLE BENEFITS. OF ARTIFICIAL RECHARGE}

Adequate storage of ground water supplies in a metropolitan area provides a high degree of protection of water supply and thus an important safety measure. Ground water supplies are much less susceptible to contamination as compared to surface reservoirs; similarly, their reduction from danger of destruction of reservoir structures and wide dispersion of outlet facilities make ground water basins of inestimable value as an emergency supply. Such considerations are of paramount importance in Los Angeles, for example, where widespread disasters such as dam failures, severed aqueducts, earthquakes, or atomic attacks could paralyze surface water facilities.

\section{ALTERNATIVES TO ARTIFICIAL RECHARGE}

Construction and operation of an artificial recharge project implies the desirability or necessity of either augmenting the existing water supply or utilizing the underground storage capacity for storage and distribution of local and imported water supplies: In order for a recharge project to be successful, field conditions must be such as to provide for appropriate storage, movement, and utilization of recharge water. The California Department of Water Resources has enumerated the following physical requirements on recharging. These are arranged in the probable order of their significance:

(a) Geology - The basin must be:suitable from the standpoint of storage capacity and transmissibility of aquifiers: 
(b). Water - Adequate water must be available for the purpose of controlled recharge.

(c) Infiltration - Recharge rates must be maintained at adequate levels in spreading areas.

(d) Drainage - Where a water table is near ground surface, adequate storage capacity in the basin for recharging must be provided.

(e) Water Quality - Recharged water must be chemically compatible with existing ground water.

(f) Recovery Efficiency - Pumping lifts must not be excessive, installed pumping capacity must be efficiently used, and quality of water recovered must be satisfactory.

If a limitation exists on one or more of the physical requirements for recharging, the only alternative is surface storage. Because the purpose of an artificial rechargé project is to store and deliver an adequate water supply at a minimum cost, recharging must be considered in competition with the alternative of surface storage and distribution. Implied in this is that the cost of pumping recharged water must be included to deliver water to a point of use.

Although artificial recharge in particular situations may, not be able to store and supply water at a lower cost than surface facilities, surface storage alone will be inadequate to meet ultimate water requirements of California. Furthermore, surface storage will become steadily more costly as the remaining combinations of good dam sites with surface reservoir sites of adequate storage capacity are exhausted. In general, capital expenditures for artificial recharge will be less than for equivalent surface storage facilities; however, the acquisition of land and rights of way in highly urbanized areas may present major economic problems. 


\section{INSTITUTIONAL AND. FINANCIAL ARRANGEMENTS}

In 1958 the 276 artificial recharge projects in California were operated by 54 agencies, most of which were various types of public water districts. 4 Projects were financed by (a) sale of general obligation bonds, (b) revenues from sales of water, power, property, water rights, leases, etc., and (c) direct assessments.

In 1955 the California legis lature enacted.a Water Replenishment District Act.specifically designed to meet the assessment problems attending artificial recharge projects. Districts organized under this act are authorized to levy assessments in proportion to the amount of water pumped from underground supplies. This is of particular importance in making equitable assess ments of those holding appropriative and prescriptive rights to use water on non-overlying land. The organization of water replenishment districts is presently limited to the counties. of Santa Barbara, Ventura, Los Angeles, San Bernadino, Orange, Riverside, and San Diego.

The powers of a water replenishment district are very broad, as indicated by the following sections of the California Water Code:

"60220. A district may do any. act necessary to replenish the ground water of said district.

"60221.. Without being limited to the following enumerations, a district. may, among other things, but only for the purposes of replenishing the ground water supplies within the district:

(a) Buy. and sell water;

(b) Exchange water;

(c) Distribute water to persons in exchange for ceasing or reducing ground water extractions; 
(d) Spread, sink and inject water into the underground;

(e) Store, transport, recapture, reclaim, purify, treat or otherwise manage and control water for the beneficial use of persons or property within the district;

(f) Build the necessary works to achieve ground water replenishment.

"60222. A district may take any action necessary to protect or prevent interference with water, the quality thereof, or water rights of persons or property within the district, subject to the limitations contained in Section 60230 .

"60223. For the purposes of replenishing the ground water supplies within the district, a district may do any act in order to put to beneficial use any water under its control or management."

The powers of a district further include the right of eminent domain, the right to cause assessments and/or charges to be levied, and the right to carry on technical and other investigations. A district may borrow money, incur indebtedness, issue bonds, cause taxes to be levied, fix rates for services, and fix rates at which water shail be sold for replenishment purposes. It may also act jointly or cooperate with any entity, public or private, to the end that purposes and activities may be fully and economically performed. 10

Central and. West Basin Replenishment District. The Central and West Basin Water Replenishment District was created by a favorable vote of the people in.1959. The district embraces the coastal plain of Los Angeles County south and west of the center of the City of Los Angeles. It has an area of 420 square miles and 29 incorporated cities are included in the area.

In its first year of operation the district levied a replenishment as. sessment, or pump tax, on all ground water pumped. The tax is revised 
annually to fit costs of purchasing Colorado River water for ground water recharge. Following are the annual charges levied by the district:

$\begin{array}{lr}\text { Year } & \begin{array}{r}\text { Pump Ta } \\ \text { Dollars/acr }\end{array} \\ 1960-61 & \$ 3.19 \\ 1961-62 & 5.75 \\ 1962-63 & 6.63 \\ 1963-64 & 6.58\end{array}$

The district purchases.water from Metropolitan Water District at the replenishment rates shown in Table 2. It also buys at the same prices 10,000 acre-feet per year of reclaimed waste water produced at Whittier Narrows by Los Angeles County Sanitation District No. 2. Revenues from sale of reclaimed water are expected to cover operating costs of the reclamation plant and to repay the loan for the plant to Los Angeles County'in 30 years.

Orange County Water District. In recent years Orange County Water District has recharged the largest volume of imported Colorado River water in Southern California. The district obtained.its funds for the first purchases of imported water in 1949 from an ad valorem tax on real property that was then restricted to 15 cents per $\$ 1.00$ of assessed value. The tax, however, did not provide enough money to buy imported water in the quantities needed to offset annual overdrafts. To meet the need to raise additional water on an equitable basis, the Orange County Water District Act was amended in 1953 by the California legislature. The changes provided for a new source of revenue in the form of a replenishment assessment, or pump tax, on the production of ground water.

The limit on the ad valorem tax was reduced from 15 cents to 8 cents per $\$ 100$ of assessed value, with funds from this source to be used to defray 
the administrative costs of the District and to buy enough water to replace in a 10-20 year period the long-time accumulated overdraft.

The pump tax has increased from $\$ 3.50$ per acre-foot of water pumped in 1953 to $\$ 6.00$ in 1962 . In the first seven years of operation the assess ment raised $\$ 5,400,000$, while in addition the ad valorem tax raised $\$ 3,5.55,000$. The District's act was amended in 1961 to permit levying an additional pump tax on the production of water for non-irrigation use. Thus, a two-rate pump tax was created favoring agricultural interests.using ground water. It also equalizes the purchase price of Colorado River water with the cost of ground water for cities connected to Metropolitan Water District lines and capable of securing imported water. Amendments also increased the ad valorem tax to purchase additional water to recharge the basin. The District expects to purchase and spread 210,000 acre-feet of water per year from the Metropolitan Water District as long as such water is available.

\section{COST COMPONENTS OF ARTIFICIAL RECHARGE PROJECTS}

Costs of proposed artificial recharge projects must be ascertained to determine economic justification and financial feasibility. ASCE Manual of Engineering Practice No. 40 (2) points out the variety and variability of costs associated with artificial recharge projects.

A convenient check list of costs for artificial recharge projects, prepared by the California Department of Water Resources, is shown in Table 3. Corrective actions for many of the operation and maintenance problems have been discussed in detail els ewhere. ${ }^{4}$

Direct comparison of costs of projects constructed at different times requires adjustment to a common base. The Engineering News-Record Construction Cost Index, defined in terms of basic construction materials 
and common labor, serves as a valid basis for comparing artificial recharge project costs. The importance of this adjustment can be noted by observing that the Index has increased from 200 in 1930 to greater than 900 in. 1963.

TABLE 3. -CHECK LIST OF OPERATION AND MAINTENANCE AND CONSTRUCTION AND ENGINEERING: COSTS FOR ARTIFICIAL RECHARGE PROJECTS ${ }^{*}$

I. Operation and Maintenance

A. Field

1. Grading

2. Cleaning shoulders

3. - Storm protection

4. Crushed rock or graveling (riprap)

5. Moving

6. Painting

7. Structure repair

8. Excavation (removing silt)

9. Miscellaneous

10. Equipment maintenance and fuels

1.1. Equipment rental

12. Spreading ground repairs - replacement

13. Discing

14. Weed control

15. Rodent control

16. Patrolling

17. Treatment of water

18. Injection well maintenance

19. Repair sides of basins due to washouts

B. Office

1. Supervision

2. Wages of personnel

3. Insurance liability (drowning)

4. Legal fees (Attorney)

5. Office expenses, such as stationery, telephone, etc.

6. Maintenance of office machines

7. Building, expenses (rent, utilities, etc.)

8. Taxes

(a), Land

(b) Agency

9. Interest

1.0. Miscellaneous 
II. Construction and Engineering

A. . Structures

1. Conduit, closed-open, ditches

2. Recording devices

3. Control, structures

4. Operator's residence

5. Flood protection of grounds

6. Overflow drainline

7. Spreading ground

(a) Dikes

(b) Basins

(c) Roads

(d) Dams

(e) Diversion

(f) Equipment housing

(g) Pipe lines

(h) Intake structures

8. Fences

9. Trespassing signs

10. Lighting

B. Engineering

1. Surveys

2. Mapping

3. Design

4. Lab tests

5. Inspection

6. Consultation

7. Preliminary study

* Furnished by California Department of Water Resources

Water Wells and Ground Water Production. Although the costs of water wells and production of ground water are not direct artificial recharge costs, they nevertheless must be considered in the total analysis of an artificial recharge project compared to an alternative surface storage and distribution project. Extraction and delivery of recharged water to a surface distribution point becomes a part of the overall project cost.

Wate'r well costs are a function of the size, depth, type, and location of wells. Heavy production wells for irrigation or nicipal water supply represent a major capital investment. They are usually constructed with 
large diameters, corrosion-resistant casings, and gravel packs around the casings to insure high yields over a long life. The following paragraphs, summarizing actual costs of irrigation and municipal wells, are indicative of the costs involved in producing ground water. Detailed cost.breakdowns for these data are available. ${ }^{l 1}$

An analysis of costs for producing ground water at one pumping plant was made by the City of Santa Ana, California, in 1960. The plant, containing two deep wells, produced water at a cost of $\$ 13.53$ per acre-foot. It should be noted that the cost of water produced included costs of wells, power, reservoir, booster station, and well buildings.

Cost of producing ground water supplies by the City of -Anaheim, California, during 1960 ranged from $\$ 10.43$ to $\$ 22.77$ per acre-foot among seven wells studied. The weighted average cost was \$13.62 per acre-foot. These costs include the Orange County Water District pump tax; without it, the weighted average cost would have been reduced to $\$ 8.65$ per acre-foot of water pumped.

A detailed breakdown of costs for producing ground water for agricultural use in Orange County, California, was preparedin 1.958 by the Orange County Water District. This analysis included capital, maintenance, and power costs for ll irrigation wells located in representative agricultural areas of the District. The average cost per acre-foot of water pumped ranged from $\$ 6.02$ to $\$ 25.95$ among the 11 wells with a weighted average of \$9.21. 'All cost data were adjusted, as needed, to apply to the 1956-58 period. These data do not include any pump tax.

In 1957 a study was made of the cost of producing ground water: for irrigation in Harmon County, Oklahoma. ${ }^{12}$. Data were collected on some 25 wells irrigating about 1.00 acres each. It was found that capital costs (fixed 
costs) varied from $\$ 2.38$ to $\$ 25.66$ per acre-foot pumped and averaged $\$ 7.20$. In addition, operating costs ranged from $\$ 1.45$ to $\$ 6.42$ per acre-foot pumped and averaged \$3.1.1. Thus, the average total cost of the water was $\$ 10.31$ per acre-foot.

Studies by agricultural economists at the University of California, Davis, have provided valuable information on costs of ground water production for irrigation in the San Joaquin.Valley, California. 13 Data were analyzed for some 11,000 wells; pumping plants ranged from 5-horsepower motors lifting less than $100 \mathrm{gal} / \mathrm{min}$. to 300 -horsepower units discharging more than $2000 \mathrm{gal} / \mathrm{min}$. The distance ground water must be lifted proved to be the most important single factor in the cost. The investment and annual per acre-foot costs of pumping water at 1959 prices ranged from $\$ 2.40$ per acre-foot at the northern end of the valley to $\$ 22.63$ per acre-foot. on the dry west side portion.

Dams. Where dams are built to store water for subsequent artificial recharge, the cost of the dam becomes part of the total cost of an artificial recharge project. Often; however, a reservoir serves other purposes as well - such as flood control, water supply, hydropower, and recreation. For multiple-purpose operation, costs must be prorated among the various benefits.

Information is available on costs of six rolled earth-fill dams constructed in 1935 and 1936 by Santa Clara Valley. Water Conservation District. Details of the dams and their costs are listed in Table 4. In the same District it was reported that low sausage dams (consisting of Page wire fencing, held in place by steel fence posts driven into the creek bed) for modified stream channel spreading cost $\$ 7.00$ per lineal foot in 1938 . 
TABLE 4.-DESCRIPTION AND COST OF SIX ROLLED EARTH-FILL DAMS CONSTRUCTED BY SANTA CLARA COUNTY WATER CONSERVATION DISTRICT ${ }^{2}$

\begin{tabular}{|c|c|c|c|c|c|}
\hline Dam & $\begin{array}{c}\text { Year } \\
\text { Constructed } \\
\end{array}$ & $\begin{array}{l}\text { Reservoir } \\
\text { Capacity, } \\
\text { (acre-feet) }\end{array}$ & $\begin{array}{c}\text { Height of } \\
\text { Crest above } \\
\text { Stream bed (ft) }\end{array}$ & $\begin{array}{l}\text { Fill } \\
\left(\mathrm{yd}^{3}\right)\end{array}$ & Cost \\
\hline Almaden & 19.35 & 9.72 & 105 & $250 ., 000$ & $\$ 446,924^{\mathrm{b}}$ \\
\hline Calero & 1935 & 9213 & 90 & 550,000 & $440,726^{b}$ \\
\hline Coyote & 1936 & 24,560 & 120 & $1,060,0.00$ & $915,218^{\mathrm{C}}$ \\
\hline Guadalupe & 1935 & 3460 & $129^{\circ}$ & 520,000 & $361,565^{b}$ \\
\hline Stevens Creek & 1935 & 3966 & 120 & 530,000 & $44], 329^{b}$ \\
\hline Vasona & 1935 & 750 & 30 & 70,000 & $197,757^{d}$ \\
\hline \multicolumn{6}{|c|}{$\begin{array}{l}{ }^{a} \text { Data furnished by the District. } \\
b_{\text {Including spillway and road. }}\end{array}$} \\
\hline
\end{tabular}

COSTS OF EXISTING ARTIFICIAL RECHARGE PROJECTS

Generalized Cost Estimates. In Table 5 is a listing of items to be considered in artificial recharge projects, together with estimated costs or remarks. This information was furnished by the California Department of Water Resources and represents conditions as of 1957. The detailed check list of cost items shown as Table 3 should also be consulted in this connection. 
TABLE 5. -ESTIMATED COSTS FOR COMPONENTS OF ARTIFICIAL RECHARGE PROJECTS IN CALIFORNIA, $1957^{*}$

\begin{tabular}{|c|c|}
\hline Capital Costs Item & Estimated Cost \\
\hline Land acquisition & $\$ 10-100 /$ acre; may be donated or leased \\
\hline Access rights-of-way & Generally same as land costs \\
\hline Buildings & $\begin{array}{l}\text { Office space, maintenance yard; and shops; may } \\
\text { be constructed, rented, or shared }\end{array}$ \\
\hline $\begin{array}{l}\text { Reservoir site and } \\
\text { clearing }\end{array}$ & $\$ 50-250 /$ acre \\
\hline Leveling & $\$ 30-100 /$ acre \\
\hline Dams & Cost may be shared by flood control \\
\hline Canals & $\$ 0.30-1.50 / \mathrm{yd}^{3}$ \\
\hline Diversion structures & $\$ 500$. and up \\
\hline Levees & $\$ 0.35-1.50 / \mathrm{yd}^{3}$ \\
\hline Roads & $\$ 100$ and up (should be gravel) \\
\hline Measuring devices & Meters, weirs, Parshall flumes, $\$ 50-500 /$ unit \\
\hline Control valves & $\$ 10-100 /$ unit \\
\hline Conduit & Concrete, metal, wopd, earth \\
\hline Fences & $\$ 0.25-1.50 / \mathrm{ft}$ \\
\hline \multicolumn{2}{|l|}{ Annual Costs } \\
\hline Water & $0-\$ 20 /$ acre $-f t$ \\
\hline Interest & $0-6 \%$ \\
\hline $\begin{array}{l}\text { Loss of income from } \\
\text { productive land }\end{array}$ & $\$ 30-100 /$ acre \\
\hline Repayment & 50 -year period \\
\hline Replacement & 50 -year period \\
\hline $\begin{array}{l}\text { Operation and mainte- } \\
\text { nance }\end{array}$ & $\begin{array}{l}\text { High variable: rodent control, flood damage, } \\
\text { silt removal, vegetation control, algae control, } \\
\text { wave action damage, structural repair }\end{array}$ \\
\hline General expenses & $\begin{array}{l}\text { Administration, personnel, equipment, legal, } \\
\text { engineering, office expenses }\end{array}$ \\
\hline $\begin{array}{l}\text { Pumping costs to recover } \\
\text { recharged water }\end{array}$ & $\$ 2-8 /$ acre/ft \\
\hline
\end{tabular}

\footnotetext{
* Data furnished by California Department of Water Resources
} 
Table V. (Con't)

Capital Costs Item

Estimated Cost

Life of Works

Levees

Wood structures ${ }^{* *}$

50 years.

Buildings

10 years

Permanent works

30 years

50 years

$* *$

Also including structures buried in the ground or exposed to water

Los Angeles County Flood Control District. Los Angeles County Flood Contrọl District operates some 23 spreading grounds. Of these, four basin grounds and three pit grounds were selected for cost analysis. The selection was made with the help of District personnel in an effort to obtain representative cost data for large and small as well as old and new spreading grounds. Costs per acre-foot of water recharge are listed in Tables 6 and 7. The following subsections contain brief descriptions of the individual grounds, and the final one describes the basis for ascertaining some of the cost figures.

Wet and dry cycles will affect recharge costs, as well as whether the source of water for spreading originates: from uncontrolled runoff or from controlled dam releases. If imported water must be purchased, an additional cost must be included.

A. Rio Hondo spreading grounds. This.is a large water-spreading area consisting of shallow basins about 5 feet deep, occupying a gross area of 423 acres (in 1959-60), and having a wetted area of 370 acres. The basins are situated in a premium location, hydrologically speaking. The land.was purchased by the District and purchase costs are regarded as average. About one-half of the water spread $(88,000$ AF) was storm water, 
TABLE 6.-COSTS OF. SELECTED SPREADING GROUNDS OPERATED BY LOS ANGELES COUNTY FLOOD CONTROL DISTRICT ${ }^{2}$

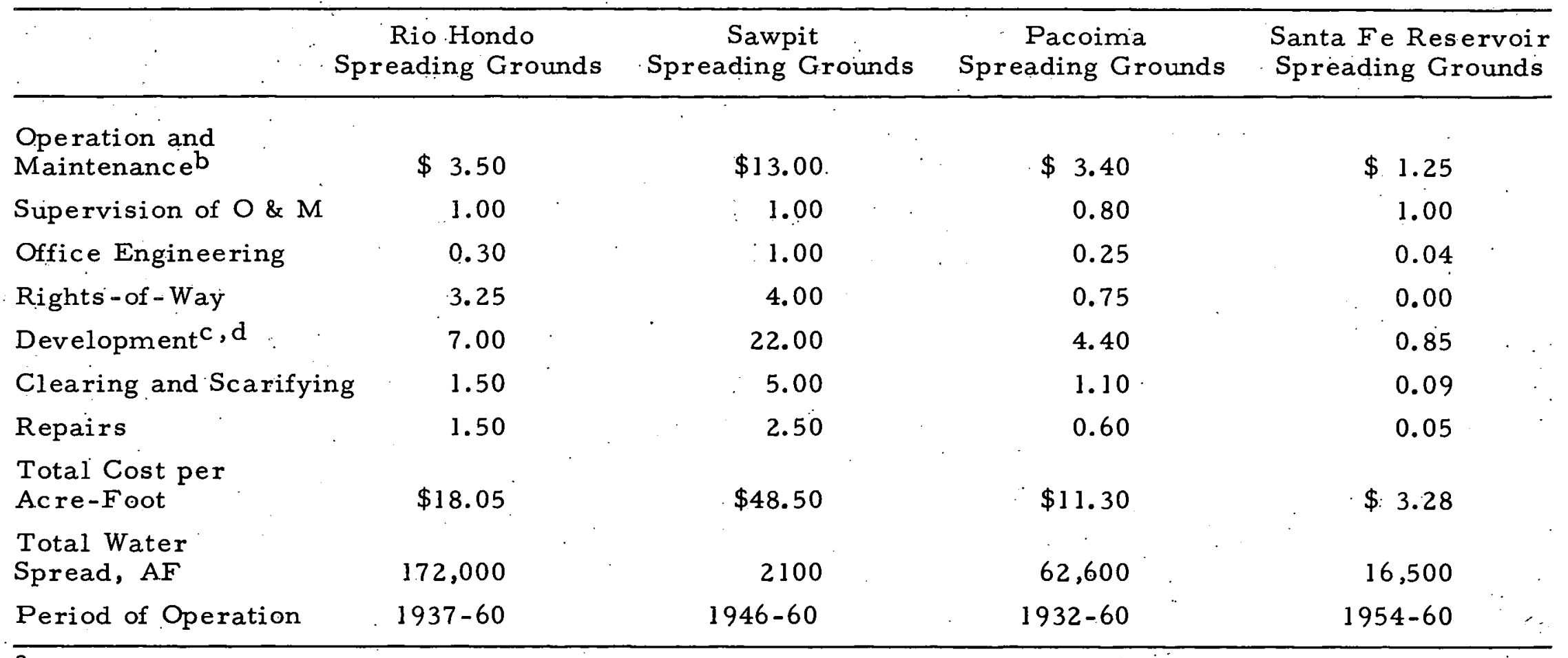

All cost figures are in dollars per acre-foot of water spread, and are actual unadjusted costs.

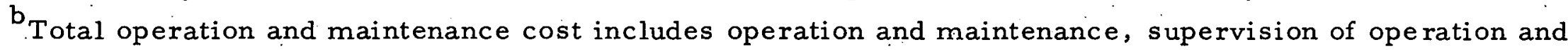
maintenance, and office engineering.

${ }^{c}$ Total capital investment includes development, clearing, and repairs:

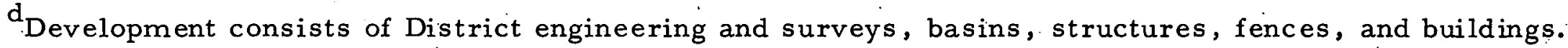


TABLE 7.-COSTS OF SELECTED RECHARGE PITS OPERATED.BY LOS ANGELES COUNTY FLOOD CONTROL DISTRICT ${ }^{a}$

\begin{tabular}{|c|c|c|c|}
\hline & $\begin{array}{l}\text { Peck Road } \\
\quad \text { Pit }\end{array}$ & $\begin{array}{c}\text { Buena Vista } \\
\text { Pit }\end{array}$ & $\begin{array}{c}\text { Eaton Spreading } \\
\text { Basin }\end{array}$ \\
\hline $\begin{array}{l}\text { Operation and Maintenance } \\
\text { Supervision of } O \& M \\
\text { Office Engineering } \\
\text { Rights-of-Way } \\
\text { Development } \mathrm{d} \\
\text { Clearing and Scarifying } \\
\text { Repairs }\end{array}$ & $\begin{array}{r}\$ 9.50 \\
8.00 \\
0.13 \\
7.90 \\
15.00 \\
0.80 \\
3.70\end{array}$ & $\begin{array}{l}\$ 0.50 \\
0.80 \\
0.03 \\
0.00 \\
0.70 \\
0.40 \\
1.25\end{array}$ & $\begin{array}{r}\$ 6.60 \\
0.80 \\
0.20 \\
4.90 \\
3.70 \\
\quad 2.70 \\
0.60\end{array}$ \\
\hline $\begin{array}{l}\text { Total Cost per Acre-Foot } \\
\text { Total Water: Spread, AF } \\
\text { Period of Operation }\end{array}$ & $\begin{array}{r}\$ 45.03 \\
1000 \\
1959-60\end{array}$ & $\begin{array}{r}\$ 3.68 \\
61.00 \\
1959-60\end{array}$ & $\begin{array}{r}\$ 19.50 \\
2500 \\
1956-60\end{array}$ \\
\hline
\end{tabular}

all cost figures are in dollars per acre-foot of water, recharged, and are actual unadjusted costs.

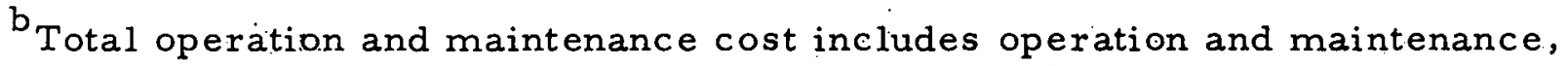
supervision of operation and maintenance, and office engineering.

${ }^{c}$ Total capital investment includes development, clearing, and repairs.

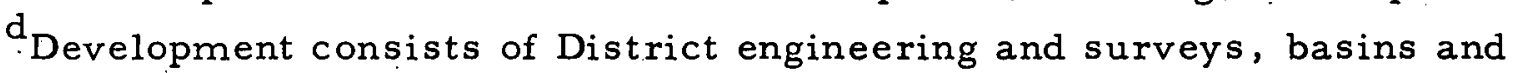
structures, and fences and buildings.

which was stored upstream by reservoirs and released as needed. There was no charge for this water. The remaining water $(84,000$. AF) was

purchased from the Metropolitan Water District.for $\$ 20.00 /$ acre-foot. Funds came from ad valorem taxes of $\$ 0.04$ per $\$ 100$ assessed valuation in a local conservation district (Zone I).

B. Sawpit Spreading Grounds. This is a small group of shallow basins about 3 feet deep, having a gross area of 11.6 acres, and a wetted area of 3.8 acres. This is regarded as an excellent location in terms of efficiency of water spreading, but costly in terms of land value. Only storm water is spread here. Costs tend to decrease with time as development is prorated over a longer period. . Land costs are figured at 4 per cent of initial cost annually throughout period of use. Office engineering is figured at 5 per cent of development for an indefinite life. This project is considered to be a relatively expensive one for water spreading. 
C. Pacoima Spreading Grounds. These are shallow spreading basins having a depth of 5 feet, occupying an area of 175 acres, and having a wetted area of 122 acres. The land was purchased by the District. Storm water is spread here; therefore, the degree of control depends upon the seasonal availability of water. This is the oldest spreading ground in the District and costs are stable.

D. Santa Fe Reservoir Spreading. Grounds. As this land is part of the flood control basin of the Corps of Engineers, there is no land cost involved. These are shallow basins $3^{\prime \prime}$ to 5 feet deep, occupying a gross area of 193 acres, and having a wetted area of 133 acres. All water spread is storm water, part being stored and part being natural flood waters. Because of zero land and water costs, together with minimum operation and maintenance costs, this project gives the least cost for water spreading.

E. Peck Road Pit. This project consists of three pits approximately 60 feet deep excavated by a gravel company and subsequently condemned and purchased by the District. The gross area is 156 acres of which 85 acres :are wetted. Only local storm water is spread. Part of the high cost of this project can be attributed to the fact that costs have been incurred since 1954 , but no water was spread until 1959.

F. Buenp Vista Pit. This is the smallest and least expensive pit operated by the District. The pit is an abandoned gravel pit purchased by the District. Its gross and wetted area is 10 acres. Storm water and excess irrigation water is recharged. There is no cost for land because the pit is figured as a flood control benefit." The actual purchase price of the land was $\$ 4000^{\circ}$ per acre.

G. Eaton Spreading Basin. This is a 60-foot-deep abandoned gravel pit purchased by the District from a gravel company. The pit has a gross. 
area of 16 acres and a wetted area of 10 acres. Only storm water is recharged and the pit is self-operating. This is considered by the District to be a typical pit in terms of size and developmental costs.

H. Method for Computing Costs. The cost of water varies with the availability of water. During a dry cycle spreading costs will slowly increase, while during a wet cycle costs will rapidly decrease.

Table 8 contains a summary of assumptions made in determining costs by the District.

TABLE 8. -BASIS FOR COST EVALUATIONS OF ARTIFICIAL RECHARGE PROJECTS BY LOS ANGELES COUNTY FLOOD CONTROL DISTRICT

A. Life of Items

Land

Land Acquired by Perpetual Easement

Permanent Structures and Basins

$\mathrm{R} / \mathrm{W}$, Surveying, Mapping

Recorders

Shelter Hous es

Fences

Wood Structures

Temporary Structures

Maintenance and Operation

Clearing and Repairs
Continuous at $4 \%$ interest

50 years

50 years

50 years

50 years

30 years

30 years

20 years

10 years

1 year

1 year

\section{B. Annual Costs}

Interest on purchase price of land at 4 per cent. (When an area is rented or leased by the District to some outside agency for us e until development, the income is subtracted from the annual interest.)

Interest and sinking fund for depreciation at 4 per cent on all items with.a limited life.

Cost per year charges are entered the first year chargeable and each succeeding year:for the life of the item.

\section{Orange County Water District. One of the largest water spreading} projects in Southern California is conducted along the Santa. Ana River in Orange County by the Orange County Water District. Costs of spreading for 
the 9-year period 1953-1962 are summarized in Table 9. Note that the total cost, exclusive of water purchase and land acquisition, for spreading more than one million acre-feet of water amounted to $\$ 449,000$ or only $\$ 0.43$ per acre-foot of water. This was distributed as follows: $\$ 0.22$ for salaries and administrative costs; $\$ 0.19$ for equipment, including gas, oil, and repairs; and $\$ 0.02$ for the prorated cost of capital investment on fixed assets, excluding land.

The District owns approximately 800 acres of land both within and outside of the Santa Ana. River. The total purchase price of the land approximates $\$ 435,000$; however, the district has received in excess of $\$ 750,000$ in royalties for sand and fill material which has been removed from these properties by permittees. For the 9-year period shown in Table 9, income from sale of sand and fill material totaled $\$ 566,274$, which considerably exceeds the sum of all operating costs. And, incidentally, removal of this material has greatly improved the lands. for spreading operations. The astute management of recharging by this District could well be a model for others to follow. Santa Clara Valley Water Conservation District. . Since the 1930's local water has been recharged in Santa Clara County by the Santa Clara Valley Water Conservation District. Originally, spreading was by the modified stream channel method; more recently, basins, or percolation ponds, have been constructed. Table 10 shows. the volume of water diverted to beneficial use (District personnel stated that more than 80 per cent was recharged underground while less than 20 per cent went for direct surface irrigation), total income, and cost per acre-foot (assuming all income was expended). Costs vary widely. from year to year, primarily because of the variability of local water available for recharge. The average cost per acre-foot for the 10 years $1953-1963$ amounts to $\$ 17.60$. 
TABLE 9. -ORANGE COUNTY WATER DISTRICT WATER SPREADING $\operatorname{COSTS} 7 / 1 / 53$ THROUGH $6 / 30 / 62^{*}$ (9-YEAR PERIOD)

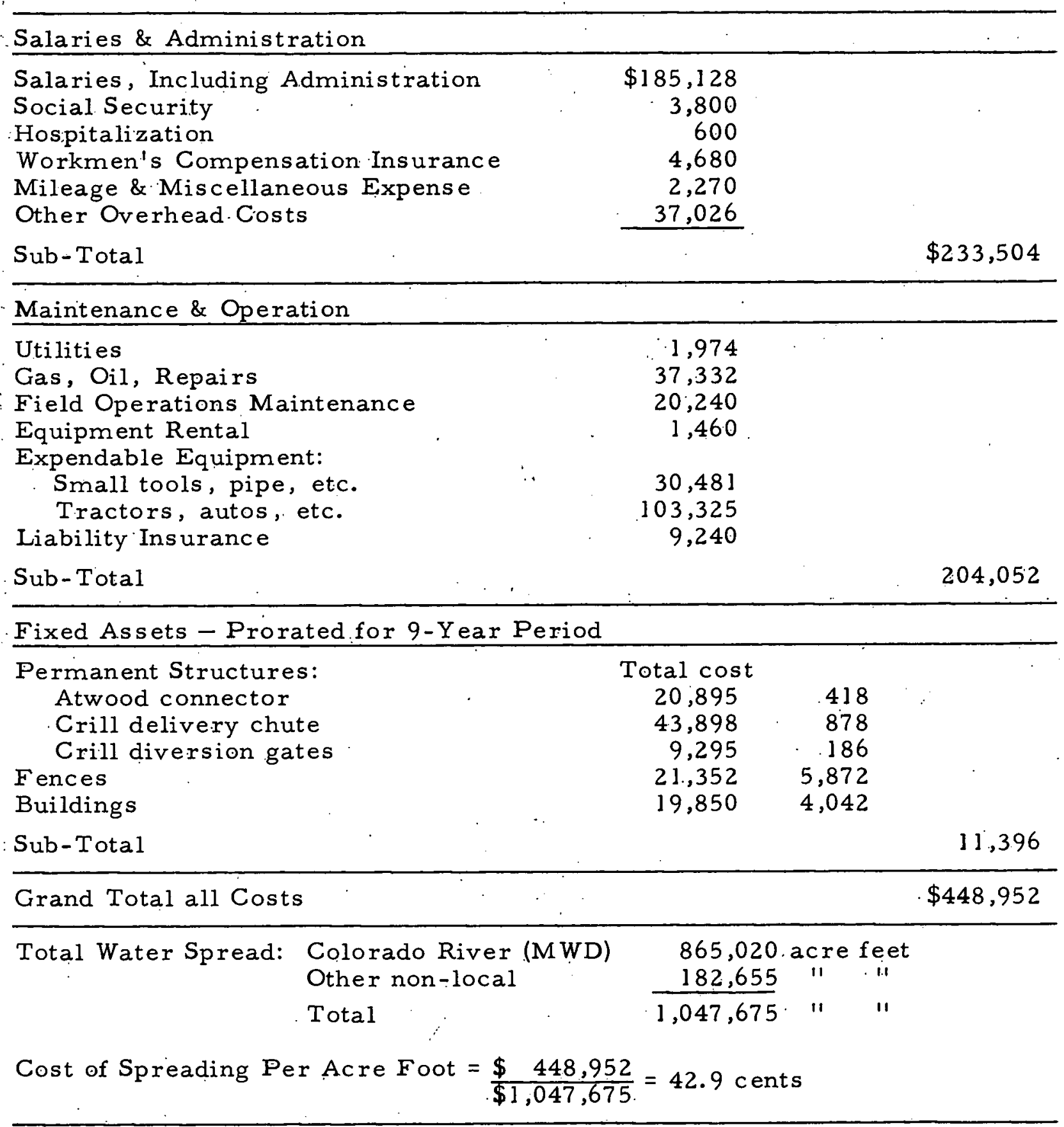

$*$

Data furnished by the District. 
TABLE 10. -COST OF WATER DIVERTED TO BENEFICIAL USE BY SANTA CLARA VALLEY WATER CONSERVATION DISTRICT, 1935-1963*

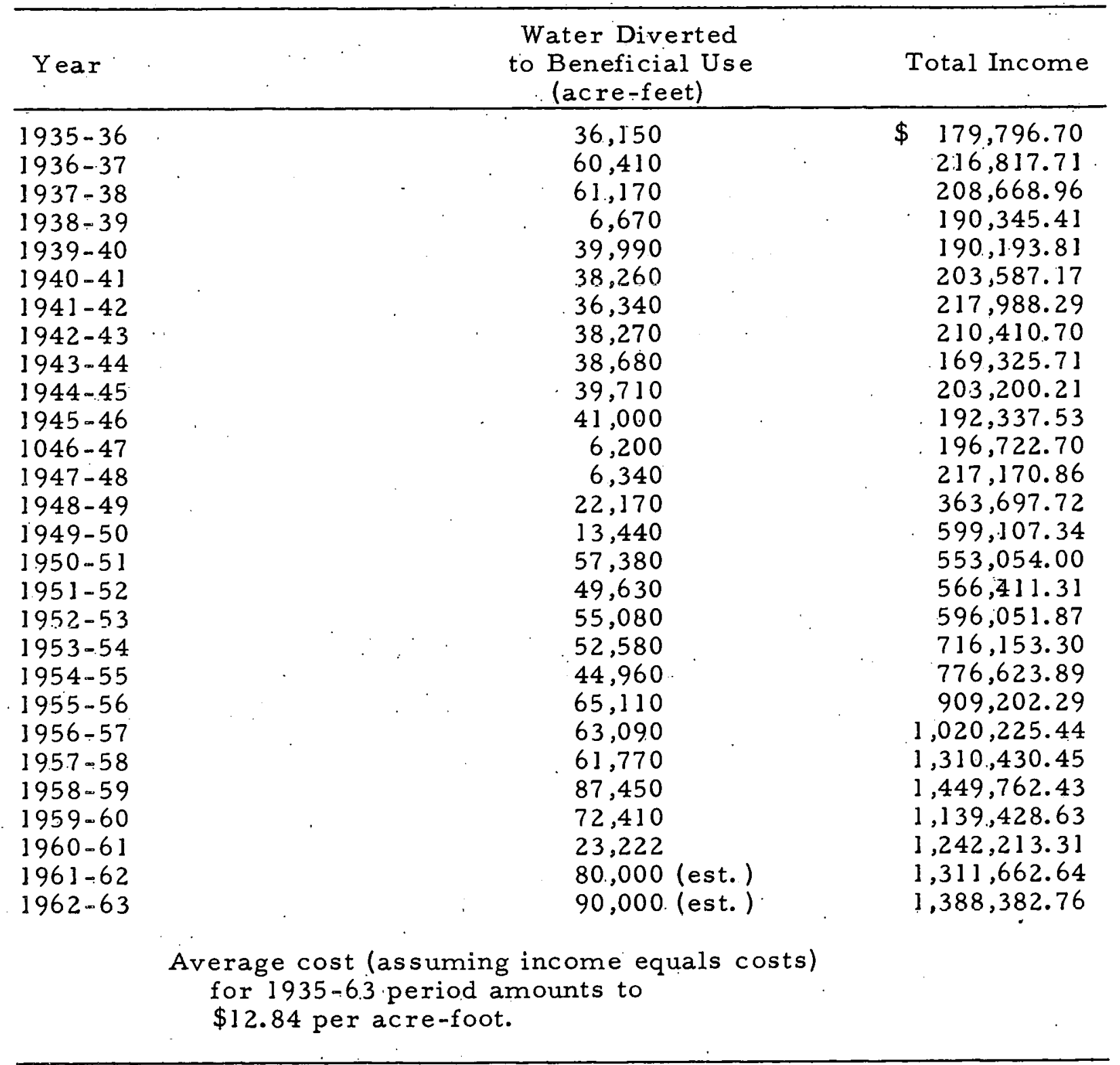

*

Data furnished by the District.

Maintenance costs on an acre-foot basis for four selected percolation ponds are shown in Table 11.

During the period 1958-1960, the District purchased stream-bed land for $\$ 17.00$ per acre, while off-stream land cost $\$ 3575$. 
TABLE 1 1. - A.V:ERAGE MAINTENANCE COSTS OF RECHARGE, SANTA CLARA VALLEY WATER CONSERVATION DISTRICT

\begin{tabular}{lcc}
\hline \multicolumn{1}{c}{ Area } & Period & $\begin{array}{c}\text { Maintenance Costs } \\
\text { (dollars per acre-foot) }\end{array}$ \\
\hline Coyote Percolation Ponds & $1936-1961$ & $\$ 0.13$ \\
Los Gatos Percolation Ponds & $1959-1961$ & 0.07 \\
Penitencia Percolation Ponds & $1938-1957$ & 1.38 \\
Penitencia Percolation:Ponds & $1957-1963$ & 8.05 \\
Main Avenue Percolation Ponds & $1954-1962$ & 1.37 \\
\hline
\end{tabular}

With concrete gunning machines, 19.4 miles of canal were concrete-

lined at a cost of $\$ 0.42$ per square foot. Hand clearing of aquatic weeds and algae in 20.5 miles of canals cost $\$ 6820$ in 1959. However, in 1960 using Aquilan, a new chemical herbicide from Shell. Chemical Company, the cost was greatly. reduced. It was estimated in 1961 that the cleaning with this chemical could be done for $\$ 2180$ on an annual basis.

Separan AP30, a new synthetic polymer designed as a flocculating chemical, was tested in 1959. Treatment consisted of adding the solution to a canal upstream from percolation ponds. With a concentration of $0.225 \mathrm{ppm}$ of Separan in the water, turbidity was reduced from $618 \mathrm{ppm}$ to $91 \mathrm{ppm}$ on an 8-cfs.flow for a cost of $\$ 0.61$ per acre-foot.

Peoria, Illinois, Recharge Pits. In the last 10 years recharge pits were constructed adjoining the Illinois River at Peoria, Illinois, in an effort to combat the overdraft resulting from heavy industrial pumping. ${ }^{14}$ River water, chlorinated but unfiltered, was released into the pits continuously, except in the summer months when river temperatures were high. The pits, located in highly permeable alluvium, accepted the water readily; cleaning was necessary only on an annual basis in most instances. The pits were constructed as an experiment by the Illinois State Water: Survey, but their success has warranted their continued operation by the City of Peoria. 
A summary of costs for one pit during 1954-56 and for two pits during 1956-1959 is presented in Table 12. Note that the unit operating cost drops significantly for two pits as compared with one pit.

Miscellaneous Cost Data. Construction and engineering cost data for several artificial recharge projects in these Southern California counties were assembled by the California Department of Water Resources and are reproduced as Table 13.

\section{CONCLUSION}

On the basis of economic data on projects to artificially recharge ground water presented in this paper, it is clear that the variables governing costs and benefits of artificial recharge preclude development of any concise summary. It is believed, however, that the data presented can be of assistance to engineers concerned with planning and designing such projects. Certainly, continued growth of the method requires that the economic feasibility of each. new project can be demonstrated.

\section{ACKNOWLEDGMENTS}

The preparation of this report would not have been possible without the excellent cooperation of several agencies and organizations in California. Valuable cost data on artificial recharge were provided by the California Department of Water Resources, Los Angeles County Flood Control. District, Orange County Water District, and Santa Clara Valley: Water Conservation District. Costs of Colorado River water were furnished by the Metropolitan Water District of Southern California. This paper is abstracted from a report (Ref. 11). prepared under contract with the University of California Ernest O. Lawrence Radiation Laboratory, Livermore, California (work performed under the auspices of the U.S. Atomic Energy Commission). 
TABLE 12.-COST OF ARTIFICIAL RECHARGE AT PEORIA, ILLINOIS, PITS 13

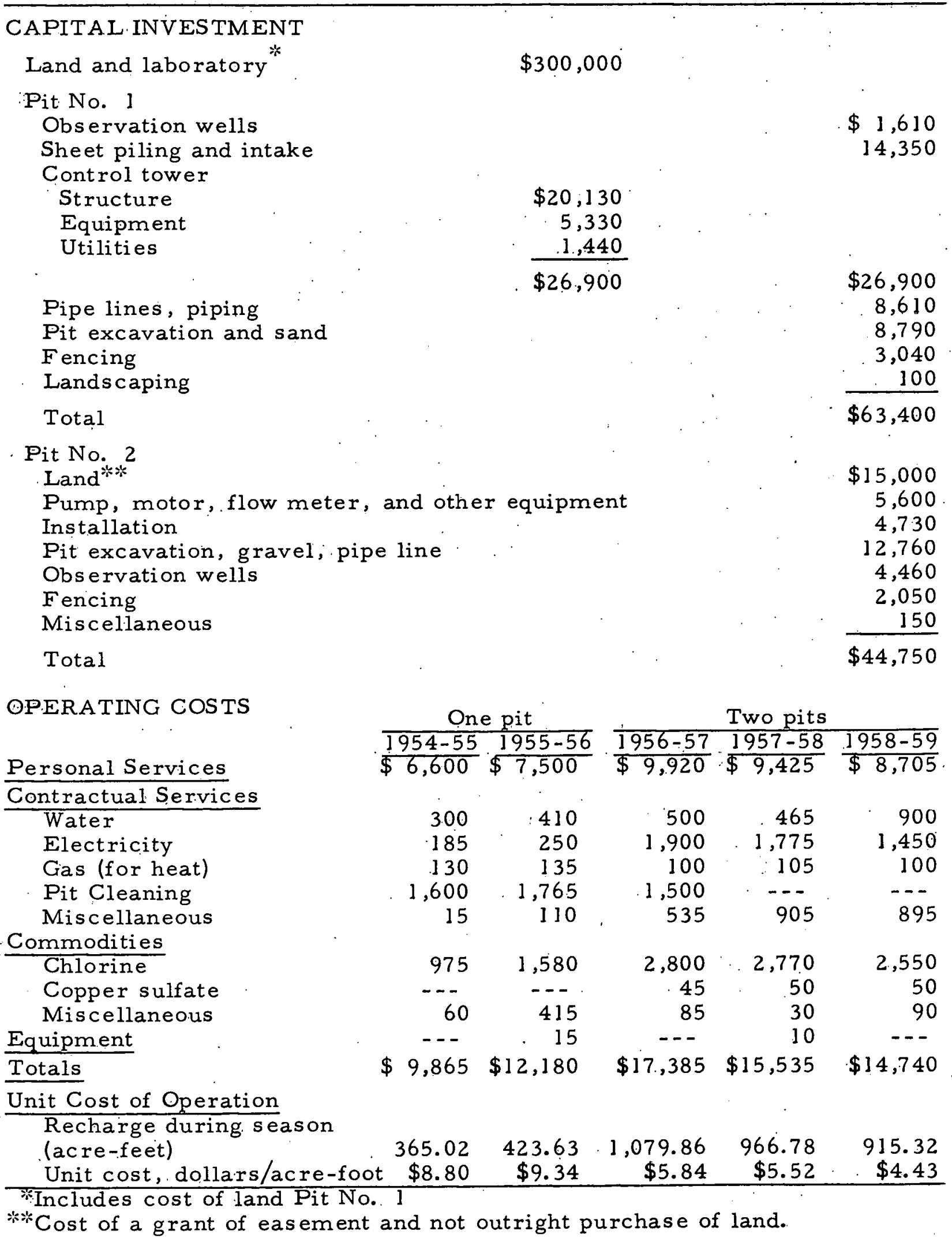


TABLE 13.-CONSTRUCTION AND ENGINEERING COST FOR ARTIFICIAL RECHARGE PROJECTS IN SOUTHERN CALIFORNIA**

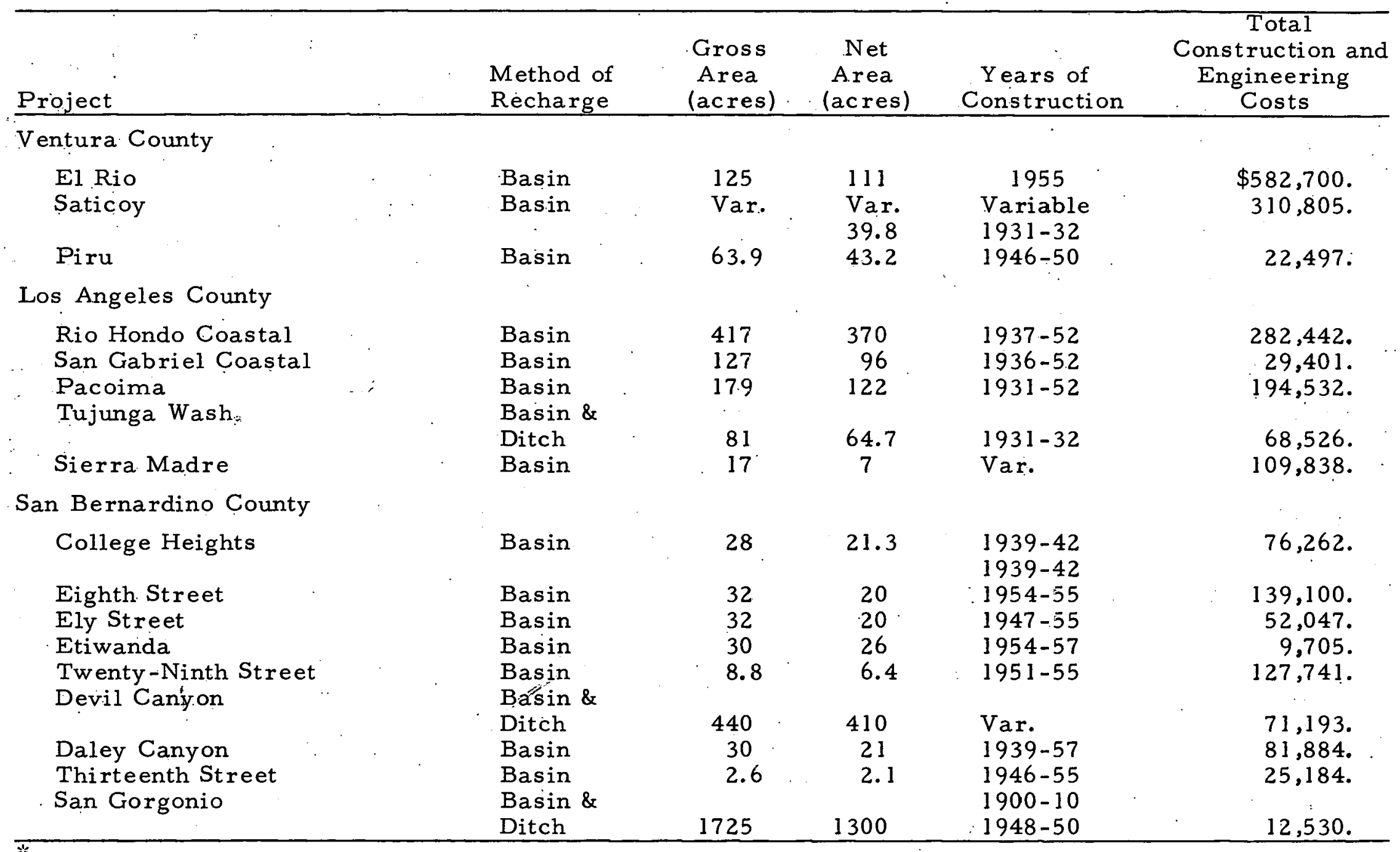

\footnotetext{
"Data furnished by California Department of Water Resources.
} 


\section{REF ERENCES}

${ }^{2}$ Committee on Ground Water,. Ground Water Basin Management, "Manual of Engineering Practice No. 40," ASCE,.New York, 160 pp., 1961.

${ }^{3}$ Todd, D. K. , Ground Water Hydrology, .J. Wiley \&: Sons, New: York, 336 pp. , 1959.

${ }^{4}$ Richter, R. C., and R. Y. D. Chun, "Artificial-Recharge of Ground Water Reservoirs.in California," Proc. Amer. Soc. Civil Engrs., Vol. 85, No. IR-4, pp. 1-28, Dec. 1959.

${ }^{5}$ Muckel,.D. C.., "Replenishment of Ground Water:Supplies by Artificial Means," Tech. Bull. No. 1195, U. S. Dept. of Agriculture, Washington, D. C. , 51 pp. , 1959.

${ }^{6}$ Todd, D. K. , "Annotated Bibliography on Artificial Recharge of Ground Water through. 1954," U. S. Geological Survey Water-Supply Paper 1477, Washington, D. C. , 115 pp. 1959.

${ }^{7}$ Revelle, R., "Water," Scientific American, Vol. 209, No. 3, pp. 92-108, September 1963.

${ }^{8}$ Renshaw, E. F., "Value of an Acre-Foot of Water,". Jour. Amer. Water Works Assoc., Vol. 50,pp. 303-309, 1958.

${ }^{9}$ Miller, D. T. (editor), "Report for the Fiscal Year July 1, 1.961, to June 30, 1962, "The Metropolitan Water District of Southern California, Los Angeles, California, 165 pp., 1962.

10"Report on Proposed.Central and West Basin Water Replenishment District," California Dept. of Water Resources, Sacramento, 76 pp. July 1959.

${ }^{11}$ Todd, D. K., Economics of Ground Water Recharge by Nuclear and Conventional Means, UCRL-7850, Univ. of California Lawrence Radiation Lab., Livermore, California 135 pp., 1964. 
${ }^{1.2}$ Davis, K. C. and J. F. Meek, "Economics of Ground Water Development on Farms in: Southwestern Oklahoma:" Oklahoma Agric. Exp.: Sta. Bull. B-499, 30 pp..; Nov.: 1957.

13 Moore, C: V., and T. R. Hedges, "Irrigation Costs of Pumping in the Sạn Joaquin Valley,"' California Agriculture, pp. 3-4; October 1960.

${ }^{14}$ Suter, M. , and R. H. Harmeson, "Artificial Ground-Water Recharge at Peoria, Illinois," Bull. 48, Illinois State Water Survey, Urbana, 48 pp. , 1960. 
This report was prepared as an account of Government sponsored work. Neither the United States, nor the Commission, nor any person acting on behalf of the Commission:

A. Makes any warranty or representation, expressed or implied, with respect to the accuracy, completeness, or usefulness of the information contained in this report, or that the use of any information, apparatus, method, or process disclosed in this report may not infringe privately owned rights; or

B. Assumes any liabilities with respect to the use of, or for damages resulting from the use of any information, apparatus, method or process disclosed in this report.

As used in the above, "person acting on behalf of the Commission " includes any employee or contractor of the commission, or employee of such contractor, to the extent that such employee or contractor of the Commission, or employee of such contractor prepares, disseminates, or provides access to, any information pursuant to his employment or contract with the Commission, or his employment with such coritractor. 